\title{
Effect of phentolamine on atrioventricular conduction in man assessed by recording His bundle potential
}

\author{
A. H. Khan, D. R. Boughner, and R. Haider \\ From the Department of Medicine (Clinical Cardiology), \\ Royal Postgraduate Medical School, Hammersmith Hospital, \\ Du Cane Road, London
}

The effect of phentolamine on atrioventricular conduction was studied in 6 patients using the technique of recording the His bundle potential. Right atrial pacing was used in order to keep the heart rate constant before and after administration of the drug.

Increasing the heart rate by right atrial pacing resulted in a progressive increase in the $P H$ interval, which represents atrial and atrioventricular conduction time, but had no effect on the $H V$ interval, which represents intraventricular conduction. Ten mg phentolamine intravenously effectively shortened the PH interval and had no effect on the HV interval. In one patient this effect was blocked by the previous administration of $5 \mathrm{mg}$ propranolol intravenously, suggesting that the mode of action of phentolamine may be through local release of catecholamines. Our results show that phentolamine improves atrioventricular nodal conduction and has no effect on intraventricular conduction.

Phentolamine, an alpha-receptor blocking agent, has recently been used as an antiarrhythmic agent. Oral administration of phentolamine was effective in abolishing or greatly diminishing the number of ventricular extrasystoles in most of the patients studied by Gould, Gomprecht, and Zahir (197I). It was also pointed out by the same authors that in some of their patients phentolamine was successful in abolishing ventricular extrasystoles when other antiarrhythmic drugs like procainamide had failed. The mechanism of action of phentolamine as an antiarrhythmic agent remains unknown. It was the purpose of this investigation to study the effects of phentolamine on atrioventricular conduction by recording the His bundle potential. Since Scherlag et al. (1969) introduced the technique of recording His bundle potentials in man it became possible to determine the atrial, atrioventricular nodal conduction time, denoted by the PH interval, and intraventricular conduction time, denoted by the HV interval, separately. The effect of phentolamine was studied on the atrioventricular nodal conduction time and intraventricular conduction time with the help of the technique of recording His bundle potentials.

Received 16 March 1972.

\section{Subjects and method}

Six patients were studied who already had some degree of conduction abnormality and they were being studied to locate precisely the conduction delay by recording the $\mathrm{His}$ bundle potential. Phentolamine was given to study its effect on atrioventricular conduction in these patients after obtaining informed consent. Clinical details of each patient are given in Table $I$.

Patients were studied in the supine position without premedication. A size 6 bipolar pacing catheter was introduced by percutaneous puncture of the right femoral vein by the Seldinger technique and positioned under fluoroscopic control beneath the septal leaflet of the tricuspid valve to record the His bundle potential. The proximal terminals of the catheter were attached to the electrocardiogram amplifier, and the bipolar His electrogram was recorded at a frequency setting of $40-500 \mathrm{~Hz}$ at a paper speed of $200 \mathrm{~mm} / \mathrm{sec}$ on an Electronics for Medicine DR8 similtrace recorder. A simultaneous surface electrocardiogram lead was also recorded in addition to the His bundle potential. A Zucker bipolar pacing catheter was placed at the junction of the superior vena cava and right atrium for pacing purposes in order to keep the heart rate constant. The $\mathrm{His}$ bundle potential, in addition to atrial and ventricular potential, was recorded at identical paced heart rates from roo$160 /$ minute before and 5 minutes after the slow injection of ro $\mathrm{mg}$ phentolamine intravenously. 
TABLE I Clinical data of patients studied

\begin{tabular}{|c|c|c|c|c|c|}
\hline $\begin{array}{l}\text { Case } \\
\text { No. }\end{array}$ & Age & Sex & Medication & Electrocardiogram findings & Diagnosis \\
\hline $\mathbf{I}$ & 58 & $\mathrm{~F}$ & Diuretics & $\begin{array}{l}\text { Normal sinus rhythm; } \\
\text { left atrial enlargement; } \\
\text { first-degree AV block }\end{array}$ & $\begin{array}{l}\text { Rheumatic heart disease; } \\
\text { mitral stenosis }\end{array}$ \\
\hline 2 & 50 & $\mathbf{F}$ & Prednisone & First-degree AV block & Sarcoidosis \\
\hline 3 & 50 & $\mathbf{M}$ & - & $\begin{array}{l}\text { Normal sinus rhythm; } \\
\text { bilateral bundle-branch block }\end{array}$ & $\begin{array}{l}\text { Intermittent complete heart } \\
\text { block; Adams-Stokes attacks }\end{array}$ \\
\hline 4 & 67 & $\mathbf{M}$ & - & $\begin{array}{l}\text { Normal sinus rhythm; } \\
\text { bilateral bundle-branch block }\end{array}$ & $\begin{array}{l}\text { Intermittent complete heart } \\
\text { block; Adams-Stokes attacks }\end{array}$ \\
\hline 5 & 15 & $\mathbf{M}$ & 一 & $\begin{array}{l}\text { Severe sinus bradycardia with } \\
\text { junctional premature beats }\end{array}$ & Syncope \\
\hline 6 & 45 & $\mathbf{M}$ & $\begin{array}{l}\text { Propranolol, } \\
5 \mathrm{mg} \text { i.v. }\end{array}$ & $\begin{array}{l}\text { Normal sinus rhythm; } \\
\text { bilateral bundle-branch block }\end{array}$ & $\begin{array}{l}\text { Hypertrophic obstructive } \\
\text { cardiomyopathy }\end{array}$ \\
\hline
\end{tabular}

a The PH interval, denoting atrial, atrioventricular nodal conduction time, and the HV interval, denoting intraventricular conduction time, were determined before and after the administration of phentolamine. The PH interval was measured from the beginning of the pacing stimulus to the beginning of the His potential, and the HV interval was measured from the beginning of His potential to the beginning of the QRS complex on the simultaneously recorded surface electrocardiogram lead. A recording of His bundle potential with atrial and ventricular potentials is shown in Fig. $\mathrm{I}$.

\section{Results}

The measurements of $\mathrm{PH}$ and $\mathrm{HV}$ intervals at all paced heart rates are shown in Table 2. Phentolamine improved atrioventricular nodal conduction as indicated by shortening of the $\mathrm{PH}$ interval at all comparable heart rates in all cases except Case 6, which is discussed in detail below, and had no effect on intraventricular conduction as indicated by absence of any change in the $\mathrm{HV}$ intervals (Fig. 2 and 3 ).

\section{Discussion}

Large numbers of investigators (Damato and Lau, 1970; Narula et al., 1970) have shown the value of recording the His bundle potential in order to study various types of conduction disturbances and to study the effects of various drugs on atrioventricular conduction. This technique has also been found

FIG. I Recording of His bundle electrogram (top) and simultaneous surface electrocardiogram (bottom) at a paper speed of $200 \mathrm{~mm} / \mathrm{sec}$. $P S=$ pacing stimulus; $A=$ atrial potential; $H=$ His potential; $V=$ ventricular potential.

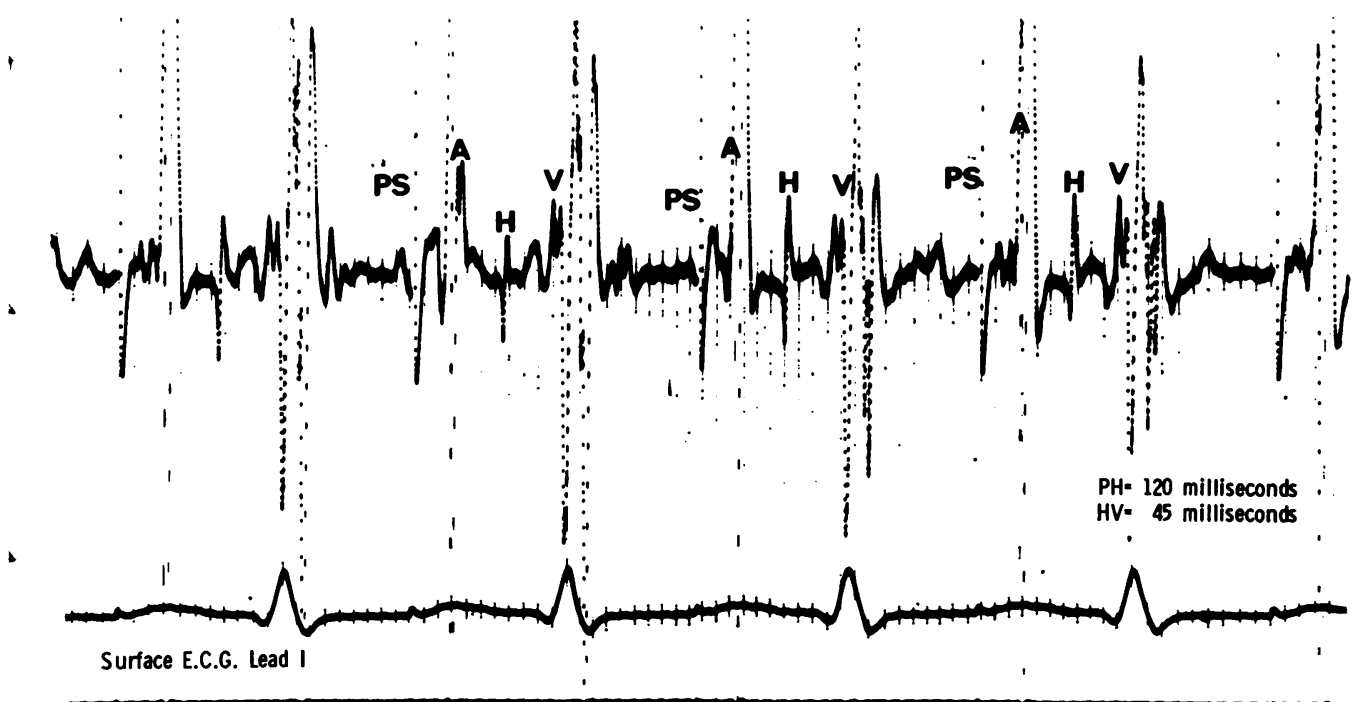


TABLE 2 Measurement of atrioventricular conduction in 6 patients before and after administration of $10 \mathrm{mg}$ phentolamine

\begin{tabular}{|c|c|c|c|c|c|}
\hline \multirow[t]{2}{*}{ Case No. } & \multirow{2}{*}{$\begin{array}{l}\text { Heart } \\
\text { rate }\end{array}$} & \multicolumn{2}{|l|}{ Control } & \multicolumn{2}{|l|}{ Phentolamine } \\
\hline & & PH interval & $H V$ interval & PH interval & $H V$ interval \\
\hline \multirow[t]{5}{*}{ I } & 100 & $\begin{array}{l}250,340,480 \\
\text { (Mobitz I block) }\end{array}$ & 70 & 160 & 70 \\
\hline & Iro & $\begin{array}{l}220,300,370 \\
\text { (Mobitz I block) }\end{array}$ & 70 & 200 & 70 \\
\hline & 120 & $\begin{array}{l}210 \\
\text { (2: I AV block) }\end{array}$ & 70 & 210 & 70 \\
\hline & 130 & $\begin{array}{l}320 \\
\text { (2: I AV block) }\end{array}$ & 70 & 200 & 70 \\
\hline & 150 & 一 & 一 & 240 & 70 \\
\hline \multirow[t]{5}{*}{2} & 100 & $\begin{array}{l}\text { I60, 190 } \\
\text { (Mobitz I block) }\end{array}$ & 55 & 一 & - \\
\hline & 110 & $\begin{array}{l}\text { I60 } \\
\text { (2: I AV block) }\end{array}$ & 55 & 130 & 55 \\
\hline & 120 & $\begin{array}{l}\text { 160 } \\
\text { (2: I AV block) }\end{array}$ & 55 & 160 & 55 \\
\hline & 130 & $\begin{array}{l}\text { 160 } \\
\text { (2: I AV block) }\end{array}$ & 55 & 160 & 55 \\
\hline & 150 & $\begin{array}{l}\text { I80 } \\
\text { (2: I AV block) }\end{array}$ & 55 & 180 & 55 \\
\hline \multirow[t]{5}{*}{3} & 100 & 160 & 90 & 120 & 85 \\
\hline & I10 & 170 & 90 & 120 & 90 \\
\hline & 120 & 175 & 90 & 120 & 85 \\
\hline & 130 & 180 & 90 & 120 & 85 \\
\hline & 150 & 180 & 90 & 130 & 90 \\
\hline \multirow[t]{5}{*}{4} & 100 & 170 & 70 & 120 & 80 \\
\hline & IIO & - & - & 130 & 80 \\
\hline & 120 & 200 & 70 & 160 & 80 \\
\hline & 130 & $\begin{array}{l}\text { I80, } 230 \\
\text { (Mobitz I block) }\end{array}$ & 70 & 160 & 90 \\
\hline & 150 & $\begin{array}{l}\text { I80 } \\
\text { (2: I AV block) }\end{array}$ & 80 & $\begin{array}{l}\text { I50, 200, } 220 \\
240,280 \\
\text { (Mobitz I block) }\end{array}$ & 90 \\
\hline \multirow[t]{5}{*}{5} & 100 & - & 一 & - & - \\
\hline & I 10 & IIO & 45 & 90 & 45 \\
\hline & 120 & 120 & 45 & IIO & 45 \\
\hline & 130 & 135 & 45 & II 5 & 45 \\
\hline & 150 & 155 & 45 & 125 & 45 \\
\hline \multirow{5}{*}{$\begin{array}{l}6 \\
\text { (After } \\
\text { propranolol } \\
5 \mathrm{mg} \text { i.v.) }\end{array}$} & 100 & 220 & 60 & 210 & 60 \\
\hline & 110 & $\begin{array}{l}\text { I90, } 230 \\
\text { (Mobitz I block) }\end{array}$ & 60 & $\begin{array}{l}\text { I70, } 2 \text { I0, 240, } 280 \\
\text { (Mobitz I block) }\end{array}$ & 65 \\
\hline & 120 & $\begin{array}{l}200 \\
(2: \text { I AV block) }\end{array}$ & 60 & $\begin{array}{l}200 \\
(2: \text { I AV block) }\end{array}$ & 65 \\
\hline & 130 & - & 一 & - & - \\
\hline & 150 & 一 & - & - & - \\
\hline
\end{tabular}

Note: When more than one number is mentioned under $\mathrm{PH}$ interval it indicates Mobitz Type I AV block with progressive delay in the AV node before the blocked beat. If only one number is mentioned it implies I:I AV conduction unless specified 2:I AV block. The block in all cases studied occurred above the His deflection.

FIG. 2 Effect of increasing heart rate on atrioventricular conduction (Case 5).

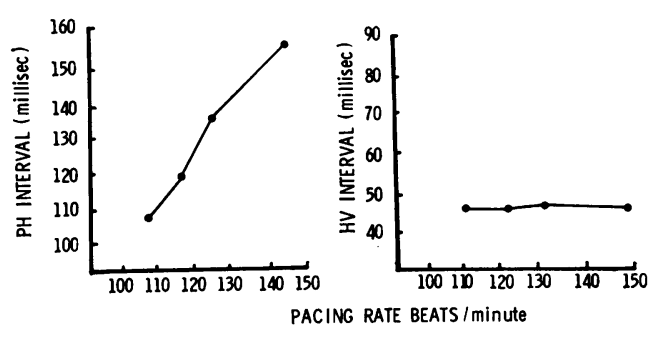

helpful in understanding the mode of production and correct diagnosis of various rhythm disturbances. The configuration and relations of the bundle of His potential have been validated by direct placement of the electrode on the His bundle during cardiotomy under experimental conditions and by its response to various physiological and pharmacological stimuli in relation to atrial and ventricular potentials (Alanis, Gonzalez, and Lopez, 1958; Hoffman et al., 1960). Leimdorfer (1952) showed that intravenous 
administration of phentolamine prevented the arrhythmias induced by nicotine sulphate and ephedrine in his experimental work on dogs. He also showed that administration of phentolamine converted methocholine-induced atrial fibrillation to normal sinus rhythm. Ettinger et al. (1969) rapidly digitalized Io normal dogs with ouabain until electrocardiographic abnormalities of rhythm

- occurred. Phentolamine administered in a dose of $0.3 \mathrm{mg} /$ minute rapidly abolished ventricular tachycardia in 4 out of 5 animals and ventricular premature beats in another 3 animals. Phentolamine has also been shown to possess positive inotropic properties. The drug was shown to increase the left ventricular - dp/dt (Gould, Zahir, and Ettinger, 1969). The administration of phentolamine at an infusion rate of $0.3 \mathrm{mg} /$ minute to patients in congestive heart failure led to striking haemodynamic improvement. The cardiac output, cardiac rate, and stroke index increased while the pulmonary artery pressure, systemic resistance, and left ventricular end-diastolic pressure fell.

Dairman et al. (1969) observed, after injection of phentolamine $(5 \mathrm{mg} / \mathrm{kg})$ to rats, that at the height of the alpha-receptor blockade the conversion of a tracer dose of tyrosine ${ }^{14} \mathrm{C}$ to norepinephrine in the heart, brain, and adrenal gland was increased threefold, with no alteration in specific activity of tyrosine in blood and tissues. It was concluded by Dairman from these observations that receptor blockade by phentolamine led to increased synthesis and release of norepinephrine in these 3 organs. Thus increased local synthesis and release of catecholamine could explain the positive inotropic action of phentolamine. The positive inotropic effect of phentolamine has also been clearly shown in acute left ventricular failure due to experimental myocardial infarction in dogs (Hood et al., I97I). They also showed that administration of propranolol, a beta-receptor blocking agent which blocks the beta-receptor mediated effect of catecholamine, will block a the positive inotropic effect of phentolamine.

The release of catecholamine also explains the improvement in conduction through atrioventricular node, as shown by the shortening of $\mathrm{PH}$ intervals in the present study. Phentolamine had no significant effect on intraventricular conduction, as indicated

- by absence of change in the HV interval. It has been shown experimentally that sympathetic stimulation or the administration of epinephrine or norepinephrine will enhance atrioventricular nodal conduction (Wallace and Sarnoff, 1964). In Case 6 it can be seen
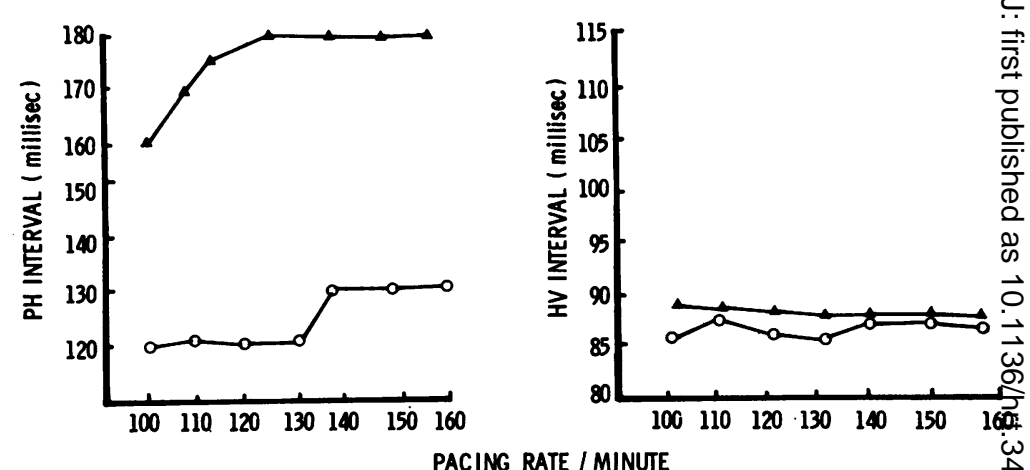

- CONTROL

- AFTER PHENTOLAMINE

FIG. 3 Effect of phentolamine on atrioventricular conduction (Case 3).

that the administration of phentolamine had no effect on the $\mathbf{P H}$ interval since this patient had already received $5 \mathrm{mg}$ propranolol as part of the study of the effect of propranolol on the haemodynamics of hypertrophic obstructive cardiomyopathy. This finding also supports the idea that phentolamine may enhance the conduction through the atrioventricular node by local release of catecholamine, and the action of released catecholamine in Case 6 has been blocked by previous administration of propranolol. Hence both the inotropic and chronotropic effects of phentolamine can be blocked by previous administration of propranolol.

The progressive increase in HV interval in Case 4 is not related to the administration of phentolamine. It probably reflects progressive fatigue of the diseased conduction tissue below the His bundle resulting from the increased number of pacing stimuli delivered by the improved conduction through the atrioventricular node after the administration of phentolamine. Another possibility is the spontaneous variation in conduction velocity in diseased distal conduction tissue since this patient had intermittent complete failure of conduction in distal conduction tissue resulting in Adams-Stokes syndrome. A grossly prolonged $\mathrm{HV}$ interval in the control recording in Case 4 and Case 3 supports the fact of greatly impaired intraventricular conduction. Both these patients had evidence of bilateral bundle-branch block on the surface electrocardiogram. It has been shown that in some patients with bilateral bundle-branch block when the atrial rate is increased by atrial pacing a delay in conduction in the His Purkinje system occurs which is manifested by further prolongation of $\mathrm{HV}$ 
interval and the impulses may be completely blocked distal to the His potential while in others there may be no further prolongation of the HV interval as seen in Case 3 (Narula and Samet, 1970; Schuilenburg and Durrer, I970).

The mechanism of the antiarrhythmic action of phentolamine is not fully understood. The concomitant release of catecholamine with administration of phentolamine may increase the low transmembrane potential of Purkinje fibres shown by Hoffman (1967) and improve conduction in certain areas of depressed conduction which may be serving as pathways for re-entrant ventricular premature beats. This change in conduction may be of small magnitude so as to be unable to be reflected as a change in HV interval, yet it may be critical to terminate the re-entrant arrhythmias. The improvement in left ventricular function may be another important factor in antiarrhythmic action of phentolamine.

We are indebted to Professor J. F. Goodwin and to Dr. C. M. Oakley for their continual interest and critical comments. Thanks also are expressed to Mr. G. Rainbow for excellent technical assistance. This study was supported by grants from the Wellcome Trust and the R. S. McLaughlin Foundation.

\section{References}

Alanis, J., Gonzalez, H., and Lopez, E. (1958). The electrical activity of the bundle of His. Fournal of Physiology, 142, 127.

Dairman, W., Gordon, R., Spector, S., Sjoerdsma, A., and Udenfriend, S. (1969). Effect of alpha blockers on catecholamine biosynthesis (abstract). Federation Proceedings, 27, 240.

Damato, A. N., and Lau, S. H. (1970). Clinical value of the electrogram of the conduction system. Progress in Cardiovascular Diseases, 13, 119.
Ettinger, S., Gould, L., Carmichael, J. A., and Tashjian, R. J. (1969). Phentolamine: use in digitalis-induced arrhythmias. Canine experiments. American Heart fournal, 77, 636.

Gould, L., Gomprecht, R. F., and Zahir, M. (1971). Oral phentolamine for treatment of ventricular premature contractions. British Heart fournal, 33, IOI.

Gould, L., Zahir, M., and Ettinger, S. (1969). Phentolamine and cardiovascular performance. British Heart fournal, 31, 154 .

Hoffman, B. F. (1967). Autonomic control of cardiac rhythm. Bulletin of the New York Academy of Medicine, 43, 1087.

Hoffman, B. F., Cranefield, P. F., Stuckey, J. H., and Bagdonas, A. A. (1960). Electrical activity during the P-R interval. Circulation Research, 8, 1200.

Hood, W. B., Jr., Singh, J. B., Abelmann, W. H., and Polansky, B. J. (197I). Positive inotropic effects of phentolamine in left ventricular failure due to experimental myocardial infarction. (Abstract). Circulation, 44, Suppl. II, 127.

Leimdorfer, A. (1952). Prevention and abolition of cardiac arrhythmias by Regitine (abstract). American fournal of Physiology, 171, 742.

Narula, O. S., and Samet, P. (1970). Wenckebach and Mobitz type II AV block due to block within the His bundle and bundle branches. Circulation, 4I, 947.

Narula, O. S., Scherlag, B. J., Javier, R. P., Hildner, F. J., and Samet, P. (1970). Analysis of the A-V conduction defect in complete heart block utilizing His bundle electrograms. Circulation, 41, 437.

Scherlag, B. J., Lau, S. H., Helfant, R. H., Berkowitz, W. D., Stein, E., and Damato, A. N. (I969). Catheter technique for recording $\mathrm{His}$ bundle activity in man. Circulation, 39, 13.

Schuilenburg, R. M., and Durrer, D. (1970). Observations on atrioventricular conduction in patients with bilateral bundle-branch block. Circulation, 41, 967.

Wallace, A. G., and Sarnoff, S. J. (1964). Effects of cardiac sympathetic nerve stimulation on conduction in the heart. Circulation Research, 14, 86.

Requests for reprints to Dr. D. R. Boughner, Department of Biophysics, Medical Sciences Building, University of Western Ontario, London 72, Ontario, Canada. 